Natural Hazards and Earth System Sciences, 5, 679-684, 2005

SRef-ID: 1684-9981/nhess/2005-5-679

European Geosciences Union

(C) 2005 Author(s). This work is licensed

under a Creative Commons License.

\title{
Probabilistic seismic hazard map for Romania as a basis for a new building code
}

\author{
L. Ardeleanu ${ }^{1}$, G. Leydecker ${ }^{2}$, K.-P. Bonjer ${ }^{3}$, H. Busche ${ }^{2}$, D. Kaiser ${ }^{2}$, and T. Schmitt ${ }^{2}$ \\ ${ }^{1}$ National Institute for Earth Physics, Bucharest, Romania \\ ${ }^{2}$ Institute for Geosciences and Natural Resources, Hannover, Germany \\ ${ }^{3}$ Geophysical Institute of University of Karlsruhe, Karlsruhe, Germany
}

Received: 28 June 2005 - Revised: 29 July 2005 - Accepted: 23 August 2005 - Published: 19 September 2005

Part of Special Issue "Seismic hazard evaluation, precursory phenomena and seismo electromagnetics"

\begin{abstract}
A seismic hazard map proposed as part of a new building code for Romania is presented here on basis of the recommendations in EUROCODE 8.

Seismic source zones within an area of about $200 \mathrm{~km}$ around Romania were constructed considering seismicity, neotectonics and geological development. The probabilistic seismic hazard assessment in terms of intensities is performed following Cornell (1968) with the program EQRISK (see Mc Guire, 1976), modified by us for use of intensities.

To cope with the irregular isoseismals of the Vrancea intermediate depth earthquakes a factor $\Omega$ is introduced to the attenuation law (Kövesligethy, 1907). Using detailed macroseismic maps of three earthquakes $\Omega$ is calculated by fitting the attenuation law to observed intensities, i.e. to local ground conditions. Strong local variation of $\Omega$ is avoided by a gridding of $0.5^{\circ}$ in longitude and $0.25^{\circ}$ in latitude. The contribution of the Vrancea intermediate depth zone to the seismic hazard at each grid point is computed with the corresponding representative $\Omega$. A seismogenic depth of $120 \mathrm{~km}$ is assumed.

The final seismic hazard is the combination of both contributions, of zones with crustal earthquakes and of the Vrancea intermediate depth earthquakes zone. Calculations are done for a recurrence period of 95,475 and 10000 years. All maps show the dominating effects of the intermediate depth earthquakes in the Vrancea zone, also for the capital Bucharest.
\end{abstract}

\section{Introduction}

In Romania there are several significant areas of seismicity (Fig. 1) with earthquakes at normal depths (less than $60 \mathrm{~km}$ ) as well as intermediate depth $(60-180 \mathrm{~km})$. The most active

Correspondence to: L. Ardeleanu

(ardel@infp.ro) zones are in the western part of Romania near the city of Timisoara (BA, DA), in the central part near Sibiu (FC) and in the north western part at Baia Mare (CM). Romania's high level of seismic hazard is mostly governed by events of the Vrancea region at the Eastern Carpathian arc bend.

To our knowledge the present study is the first seismic hazard assessment in terms of macroseismic intensities for Romania. Probabilistic seismic hazard maps in terms of horizontal peak ground acceleration were published by Musson (2000), Mäntyniemi et al. (2003) and Marmureanu et al. (2004). Musson (2000) presented maps for the Pannonian Basin (including Romania) for return periods of 100, 475, 1000 and 3000 years. For earthquakes in the intermediate depth Vrancea seismic zone he used three different attenuation models depending on the direction from the source. Mäntyniemi et al. (2003) mapped for a return period of 475 years the specific seismic hazard for the Vrancea seismic zone using depth- and azimuth-dependent attenuation functions. On the other hand Marmureanu et al. (2004) solely investigated the seismic hazard from crustal earthquakes. A deterministic approach was used by Radulian et al. (2000) by computing synthetic seismograms.

A seismic hazard map proposed as part of a new building code of Romania based on EUROCODE 8 (EC 8) is presented here in terms of macroseismic intensities. As recommended in EC 8 two maps are calculated: for a probability of exceedance of $10 \%$ in 50 years (recurrence period of 475 years) and a probability of exceedance of $10 \%$ in 10 years (recurrence period of 95 years).

\section{Probabilistic Seismic Hazard Assessment (PSHA) and treatment of the crustal earthquake zones}

Basis of the probabilistic analysis is the earthquake catalogue for SE-Europe (Shebalin et al., 1998). Epicenters and 


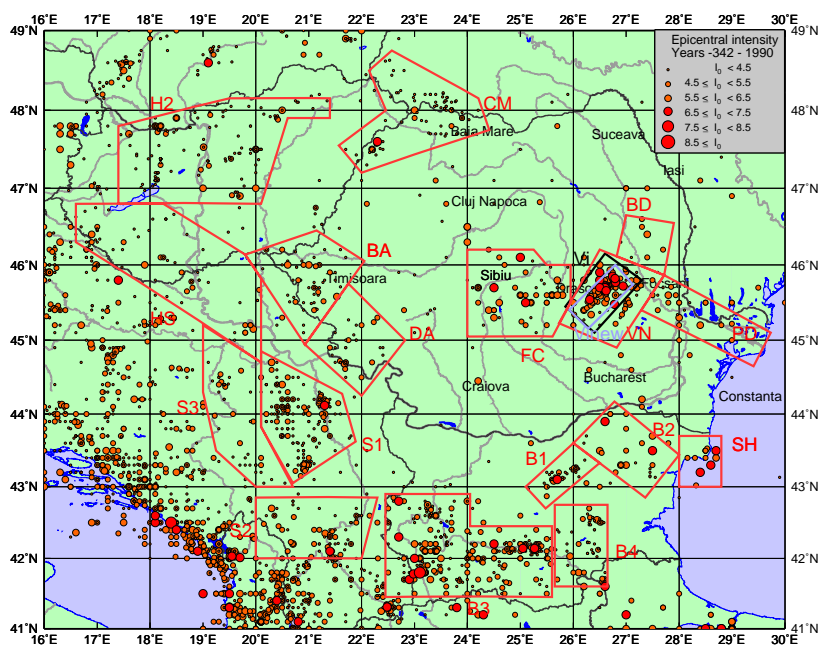

Fig. 1. Epicenter map (Shebalin et al., 1998) with the seismic source zones. Codes refer to Table 1.

seismic source zones in an area of about $200 \mathrm{~km}$ around the territory of Romania are shown in Fig. 1. The boundaries of these zones were chosen to reflect the seismicity adequately regarding tectonic units and lithospheric structure as well as the suggested zonations given by Musson (2000), Radulian et al. (2000), Bala et al. (2003) and Marmureanu et al. (2004).

As a Poisson distribution is assumed earthquakes have to be independent events. In case of more than one earthquake within 10 days and $50 \mathrm{~km}$ distance only the strongest event is used for the statistics; the others are declared as statistical dependent (pre- and aftershocks) and eliminated from the catalogue. The beginning of the time period for statistical purposes is chosen according to the assumed completeness of the catalogue for events greater than the lowest intensity value used in statistics. The intensity frequency parameters $a$ and $b$ for each zone (Table 1) are calculated with Eq. (1).

$\log N(I)=a+b I_{\text {epic. }}$

$N(I)$ is the cumulative number of earthquakes; $I_{\text {epic. }}$ is the epic. intensity.

The maximum credible earthquake for each zone is estimated (Table 1) with respect to seismicity, frequency of earthquakes, maximum observed intensity and quality of historical documents.

Some seismic regions display few and disperse seismicity. They are treated in a special way (see Table 1) to calculate the intensity frequency statistic. All earthquakes excluding those of the designed sources are assigned to the "background seismicity". The seismogenic depth of a region is defined where maximum of energy is released.

The seismicity within the Vrancea region consists of two depth horizons: normal deep (less than $60 \mathrm{~km}$ ) and intermediate deep $(60-180 \mathrm{~km})$ events. Due to extremely irregular isoseismals of the intermediate depth earthquakes their effects on the seismic hazard have to be treated separately.

The probabilistic seismic hazard for Romania is computed with EQRISK developed by McGuire (1976). It is based

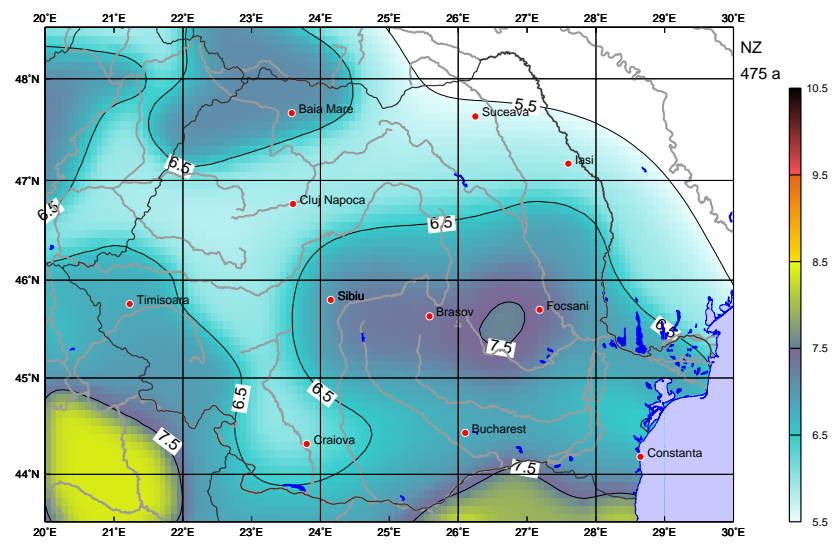

Fig. 2. Seismic hazard from source zones of normal depth for a recurrence period of 475 years; colours represent the intensities in MSK.

on the probabilistic approach of Cornell (1968). We implemented the intensity attenuation function of Sponheuer (1960) based on Kövesligethy (1907).

$I_{\text {site }}=I_{\text {epic. }}-3 \log (r / h)-1.3 \alpha *(r-h)$

$r$ is the hypocentral distance $(\mathrm{km}) ; h$ is the depth $(\mathrm{km})$; and $\alpha$ is the absorption coefficient, here $0.002 \mathrm{~km}^{-1}$.

For a hazard curve at a site EQRISK cuts all source regions into finite ring segments with their statistical parameters. Then the site intensities caused by earthquakes of each segment are calculated assuming a standard deviation of half an intensity. The sum of all contributions from all regions finally leads to the annual probability of exceedance at each grid point of the hazard map. These calculations are done for all points between $43.5^{\circ} \mathrm{N}$ to $48.5^{\circ} \mathrm{N}$ and $20.0^{\circ} \mathrm{E}$ to $30.0^{\circ} \mathrm{E}$ every $0.1^{\circ}$ in latitude and $0.2^{\circ}$ in longitude. Figure 2 shows the seismic hazard for Romania due to the earthquakes of normal depths only.

\section{Vrancea intermediate depth earthquake zone}

Macroseismic and early instrumental data have shown that the seismicity in the Vrancea zone is dominated by intermediate depth events located in a well defined volume. The epicentral area is confined to about $40 \times 80 \mathrm{~km}$. Most earthquakes occur at depths between $60 \mathrm{~km}$ and $180 \mathrm{~km}$ within an almost vertical column (e.g. Radu, 1974; Fuchs et al., 1979; Oncescu et al., 1999).

Shallower and deeper events were also recorded, however are less frequent and have only small to moderate magnitudes. Vrancea seismicity is further characterized by pronounced background activity which delineates the rupture area of the strong earthquakes (e.g. Oncescu and Bonjer, 1997).

During the last century four major earthquakes occurred: on 10 November 1940 (MW=7.7), 4 March 1977 (MW=7.4), 30 August 1986 (MW=7.1) and on 30 May $1990(M W=6.9)$. During the 4 March 1977 event 1570 people died, 11300 
Table 1. Parameters of intensity-frequency relations and input-parameters for seismic hazard calculation. The $a$ - and $b$-values are estimated using full intensity values. Half intensity values are added to the next higher intensity class. This enlarges the number of events in each class, which improves the statistical stability and is also more conservative.

\begin{tabular}{lcrrrrrrr}
\hline Region & code & $\begin{array}{r}\text { start } \\
\text { year }\end{array}$ & $\begin{array}{r}\text { time } \\
\text { interval }\end{array}$ & $\begin{array}{c}b \\
\text { value }\end{array}$ & $\begin{array}{c}a \\
\text { value }\end{array}$ & $\begin{array}{r}\text { depth } \\
\text { km }\end{array}$ & $\begin{array}{r}I_{\text {max }} \\
\text { observed }\end{array}$ & $\begin{array}{r}I_{\text {max }} \\
\text { credible }\end{array}$ \\
\hline Banat N $^{2}$ & BA & 1843 & 148 & 3.251 & 0.399 & 10 & 8.5 & 8.5 \\
Birlad $^{3}$ & BD & 1896 & 95 & 3.080 & 0.460 & 25 & 6.5 & 7 \\
Background & BG & 1817 & 174 & 3.949 & 0.453 & 10 & 8.5 & 8.5 \\
\hline Bulgaria N $^{4}$ & B1 & 1849 & 142 & 3.817 & 0.423 & 15 & 9.5 & 9.5 \\
Bulgaria NE $_{\text {Bulgaria S }}$ & B2 & 1832 & 159 & 3.705 & 0.416 & 15 & 9 & 9.25 \\
\hline Bulgaria SE & B3 & 1818 & 173 & 5.237 & 0.520 & 12 & 10 & 10.25 \\
Crisana Mamamures & B4 & 1893 & 98 & 4.063 & 0.520 & 10 & 8.5 & 9 \\
Banat S & CM & 1781 & 210 & 5.130 & 0.573 & 10 & 8 & 8.5 \\
\hline Fagaras Campulung & DA & 1864 & 127 & 3.200 & 0.399 & 12 & 8 & 8.5 \\
Hungary Central & FC & 1517 & 474 & 3.467 & 0.374 & 20 & 8.5 & 9 \\
Hungary+Serbia & H2 & 1753 & 238 & 4.472 & 0.456 & 10 & 8.5 & 9 \\
\hline Predobroudja & HS & 1738 & 253 & 5.126 & 0.573 & 8 & 8.5 & 9 \\
Shabla Zone 6 & PD & 1832 & 159 & 3.581 & 0.460 & 20 & 7.5 & 7.5 \\
Serbia E & SH & 1901 & 90 & 3.157 & 0.416 & 15 & 10 & 10 \\
\hline Kosovo & S1 & 1886 & 105 & 4.891 & 0.487 & 10 & 9 & 9.5 \\
Serbia W & S2 & 1897 & 94 & 4.678 & 0.529 & 10 & 8.5 & 9 \\
Vrancea, normal depth & S3 & 1894 & 97 & 6.081 & 0.803 & 10 & 7.5 & 8 \\
\hline Vrancea, intermediate & Vi & 1802 & 189 & 3.621 & 0.452 & 30 & 8 & 8.5 \\
\hline
\end{tabular}

${ }^{1}$ End year for all regions is 1990; usually, only events with intensities of 5.5 or more are considered.

${ }^{2}$ For the two regions DA and BA, the events are added and a common intensity-frequency statistic is done, resulting in the same $b$-value. The $a$-value is computed: for region BA using the cumulative number of events with intensity 7.0 MSK and more; for region DA using the cumulative number of events with intensity 6.0 MSK and more.

${ }^{3}$ For the two regions $\mathrm{BD}$ and $\mathrm{PD}$, the events are added and a common intensity-frequency statistic is done, resulting in the same $b$-value. The $a$-value for each region is computed, using the cumulative number of events with intensity 5.0 and more.

4 The regression curve in the cumulative intensity-frequency relation for region B1 is calculated without the single event with intensity 9.5 MSK for statistical reasons; then the strongest event has an intensity of 8.0 MSK.

${ }^{5}$ For region $\mathrm{B} 4$ the $b$-value of B3 is taken. The $a$-value for region B4 is computed using the cumulative number of events with intensity 5.0 MSK and more.

${ }^{6}$ For region SH the $b$-value of B2 is taken. The $a$-value for region SH is computed using the cumulative number of events with intensity 6.0 MSK and more.

were injured and 32500 residential and 763 industrial units were destroyed or seriously damaged, according to official data (e.g. Sandi, 2001).

With the deployment of modern seismic networks in the past decades, the accuracy of hypocenter locations increased considerably (e.g. Oncescu et al., 1999). In particular, Joint Hypocenter Determinations (JHD) showed that the Vrancea seismogenic zone has a two-dimensional geometry rather than a three-dimensional one (Oncescu, 1984; Oncescu and Trifu, 1987; Trifu et al., 1992; Oncescu and Bonjer, 1997). Recent analyses of the travel time data of the K2-network (Bonjer et al., 2000) reveal further details of the fine structure of the geometry of the Vrancea focal zone (Bonjer et al., 2005). The zone of seismic activity has a total width of about $20 \mathrm{~km}$. It broadens from about $25 \mathrm{~km}$ at depths of $60 \mathrm{~km}$ to about $60 \mathrm{~km}$ at depths of $160 \mathrm{~km}$. The earthquakes are located on two parallel planes (see blue and red circles in Figs. 3 and 4), separated by less than $10 \mathrm{~km}$. The stars represent fore- and mainshock of 17 October 2005 sequence (Bonjer et al., 2005, Radulian et al., 2005).

To calculate the $a$ - and $b$-value of Vrancea intermediate depth zone all epicenters inside $V i_{\text {stat. }}$ are used (Fig. 3). For the computation of seismic hazard the area of zone $V i_{\text {stat. }}$. was reduced to $V i_{\text {comp. }}$, according to the above well defined volume. 


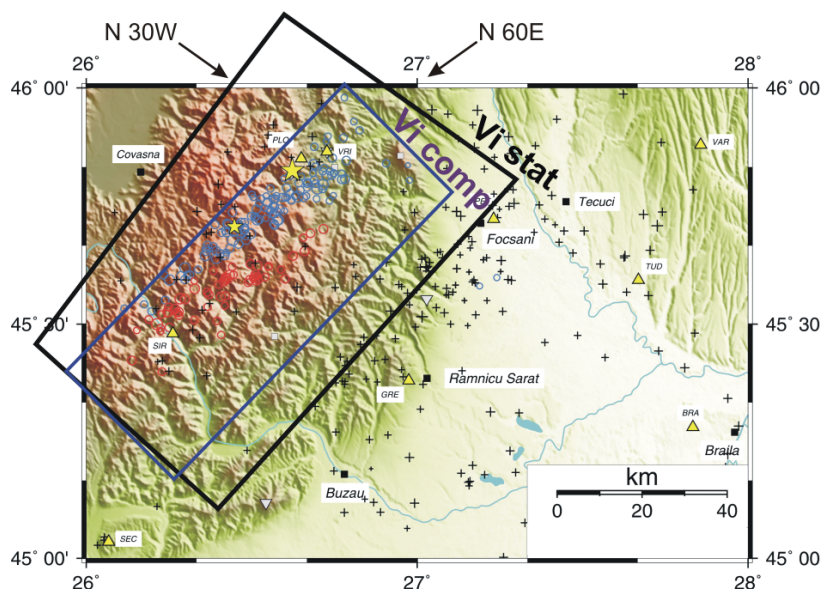

Fig. 3. JHD locations of the seismicity in the time period 19962003 at the South-Eastern Carpathian Arc bend (Bonjer et al., 2005). Blue and red circles: Vrancea intermediate depth earthquakes at two parallel active planes. Black crosses: crustal earthquakes. Large yellow star: epicenter of the event of 27 October 2004. Small yellow star: epicenter of the largest earthquake occurring in 2004 prior to 27 October (27 September, Mw=4.7). Triangles and squares: seismic stations. $V i_{\text {stat. }}$ zone for statistics, $V i_{\text {comp. }}$ zone for computation of seismic hazard.
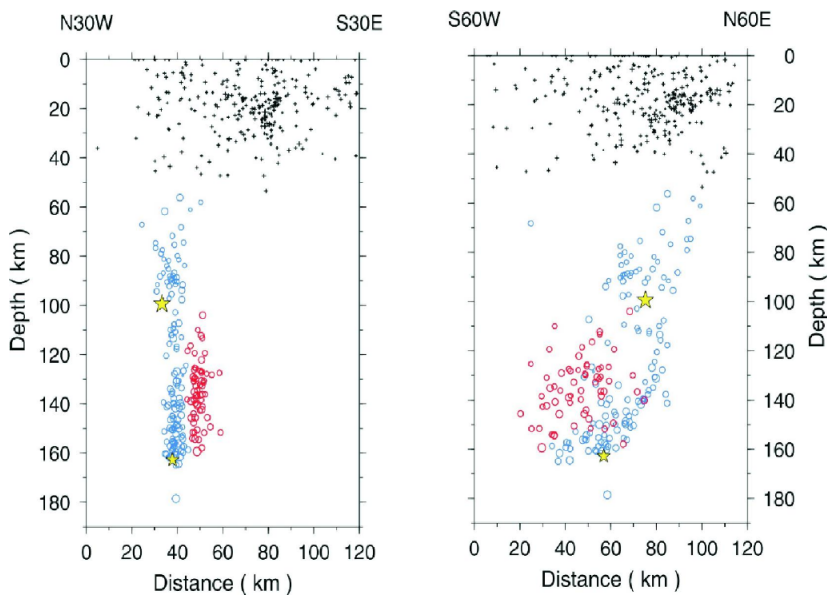

Fig. 4. Depth distribution of the earthquakes of Fig. 3 on two perpendicular, vertical cross sections in Vrancea area (for earthquakes between 1996 and 2003), striking N30W and N60E, respectively. Note the almost vertical plunge of the seismic activity on two parallel planes (left figure). Symbols and colours as in Fig. 3.

\section{Treatment of Vrancea intermediate depth zone}

Isoseismals of shallow earthquakes are almost circular shaped which is required to fulfil the assumed attenuation law of Sponheuer (1960). In contrast to them the isoseismals of earthquakes of intermediate depths are quite irregular shaped (Fig. 5). Observed intensities of the earthquakes of 4 March 1977 (Radu and Polonic, 1982), 30 August 1986 (Radu, personal communication) and 30 May 1990 (Radu and Utale, 1990) decrease in north western directions in

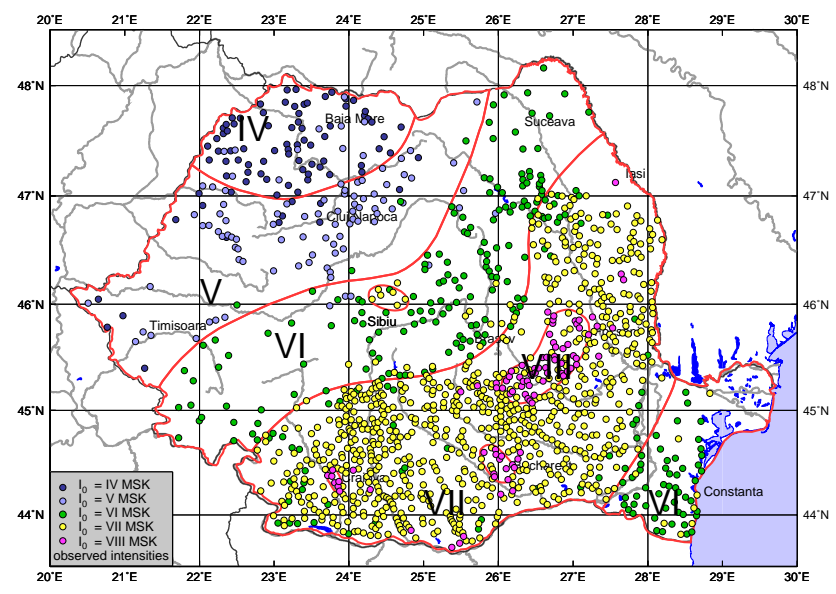

Fig. 5. Macroseismic field of the earthquake from 4 March 1977 (Radu and Polonic, 1982) with epicentral intensity $I_{0}=$ VIII-IX MSK and $h=94 \mathrm{~km}$.

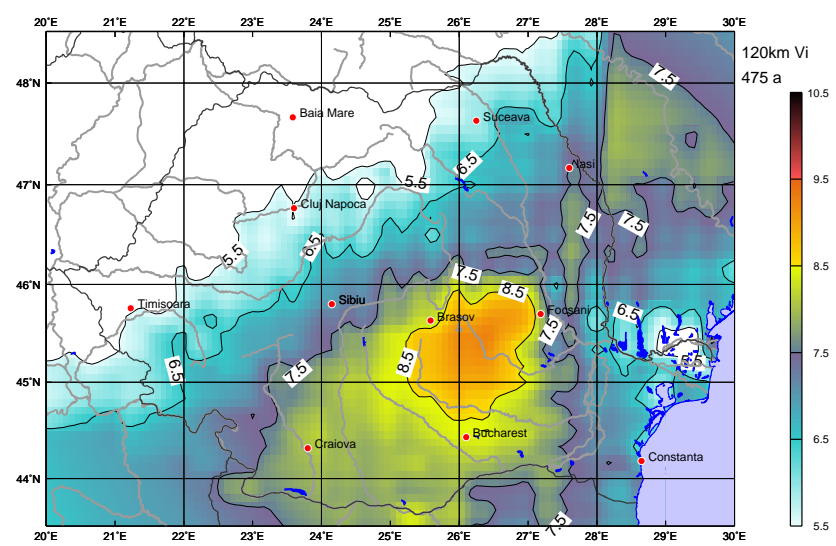

Fig. 6. Seismic hazard from Vrancea events of intermediate depth for a recurrence period of 475 years; colours represent intensities in MSK.

shorter distances than in north eastern and south western directions. Teleseismic tomography detected lower seismic velocities about $100 \mathrm{~km}$ northwest of Vrancea in an intermediate depth range of $70-110 \mathrm{~km}$ (Martin et al., 2004 ${ }^{1}$ ). However, the phenomenon of the irregular shape of isoseismals of Vrancea intermediate depth earthquakes is still not explained.

As the attenuation law does not consider spatial differences in damping, a new empirical approach is chosen to take the directionality of attenuation into account. A factor $\Omega$ is introduced to the attenuation law in Eq. (2):

$I_{\text {site }}=I_{\text {epic. }}-3 \log (r / h)-1.3 \alpha * \Omega(r-h)$

Using detailed macroseismic maps of the three strong Vrancea intermediate depth earthquakes $\Omega$ is calculated

\footnotetext{
${ }^{1}$ Martin, M., Wenzel, F., and the CALIXTO Working Group: High resolution teleseismic body wave tomography for SERomania: Imaging of a slab detachment scenario, Geophys. J. Int., under review, 2004.
} 


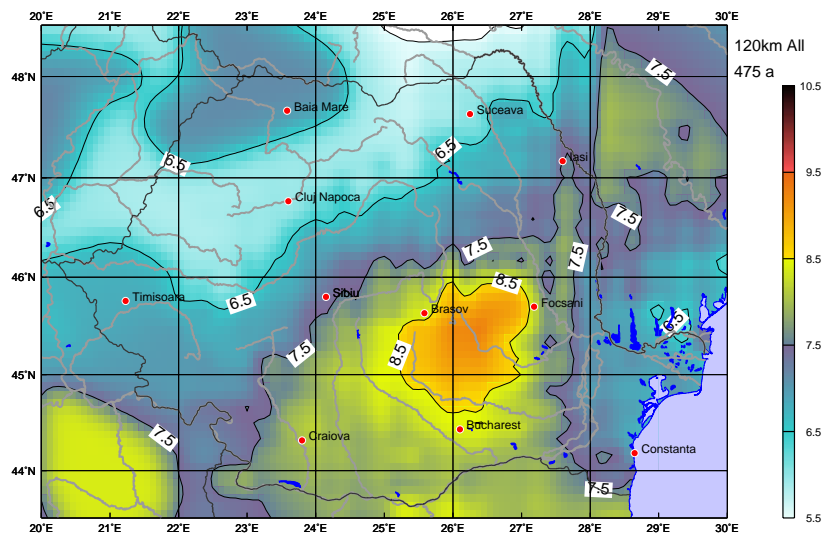

Fig. 7. Seismic hazard from all source zones for a recurrence period of 475 years; colours represent intensities in MSK.

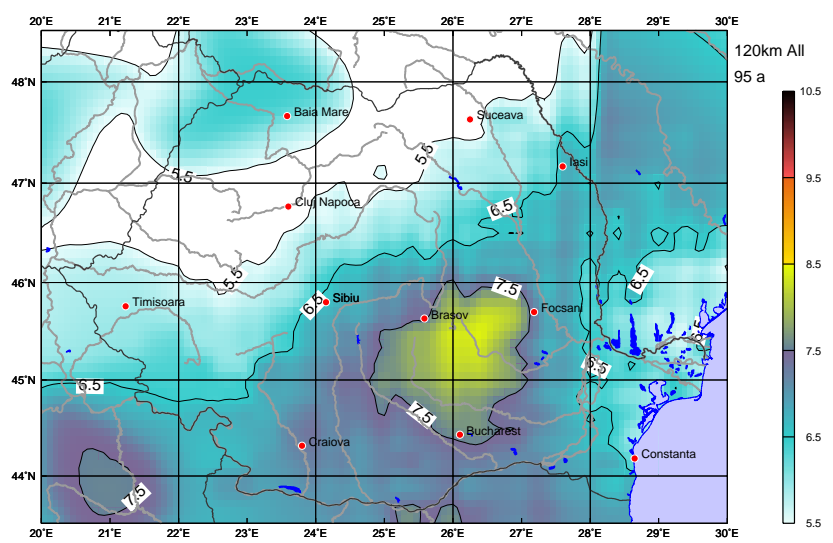

Fig. 8. Seismic hazard from all source zones for a recurrence period of 95 years; colours represent intensities in MSK.

for each observation. For simplification $\alpha$ is fixed to $0.001 \mathrm{~km}^{-1}$. Strong local variations of $\Omega$ are avoided by calculation mean values inside grid cells of $0.56^{\circ}$ in longitude and $0.25^{\circ}$ in latitude, separately for each event. The median is taken to combine all three grids. Intensities for rectangles without observations have been $2 \mathrm{D}$-interpolated respectively extrapolated.

Using the assigned $\Omega$ values for each point of observation, the seismic hazard of the Vrancea Intermediate Depth Zone $(V i)$ is calculated in the same way as for the crustal zones. A seismogenic depth of $120 \mathrm{~km}$ is assumed for $V i$ source zone. Figure 6 shows intensities for a recurrence period of 475 years.

\section{Results}

The final seismic hazard map for a recurrence period of 475 years in Fig. 7 is a combination of the map for source zones of normal depth (Fig. 2) and that for Vrancea intermediate depth zone (Fig. 6). Macroseismic observations for intermediate depth earthquakes are only available for Romania. Therefore our seismic hazard assessment is only valid for the Romanian territory.

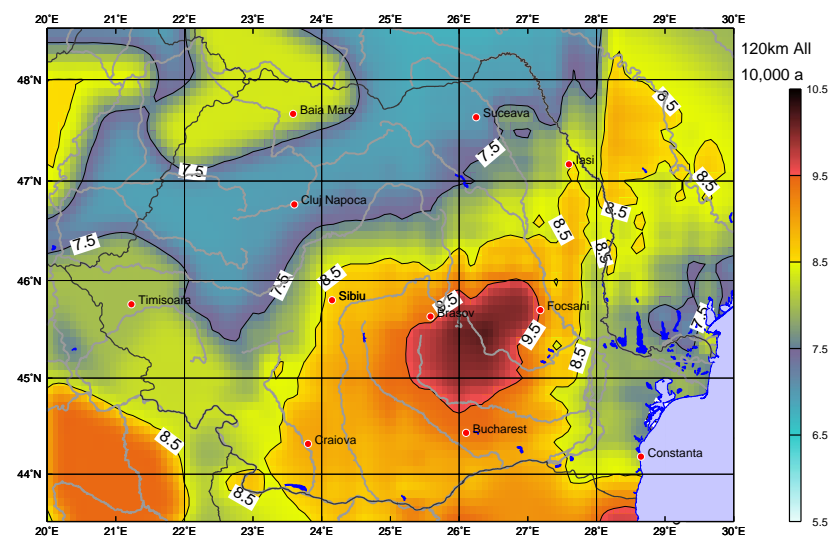

Fig. 9. Seismic hazard from all source zones for a recurrence period of 10000 years; colours represent intensities in MSK.

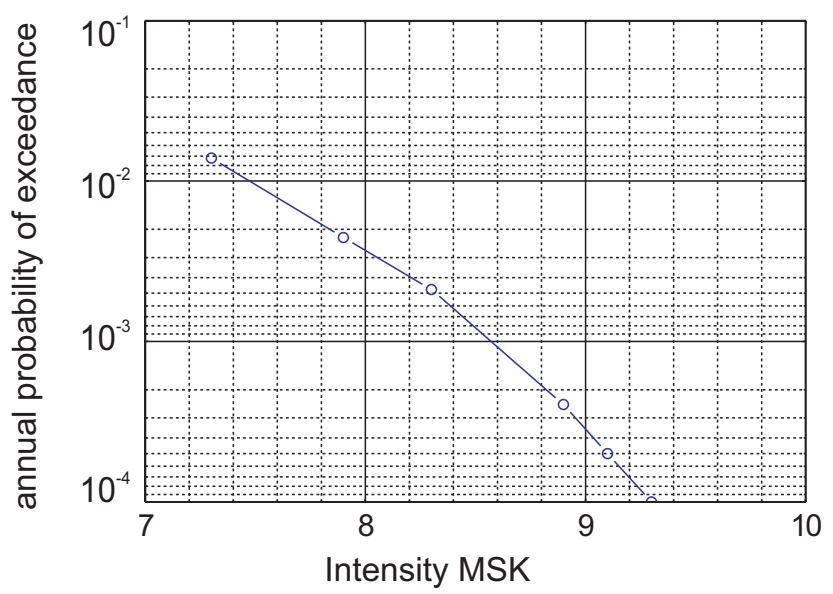

Fig. 10. Seismic hazard curve for Bucharest.

The intermediate depth earthquakes of the Vrancea Zone occur at depths of about $60 \mathrm{~km}$ to $180 \mathrm{~km}$. To estimate the depths' influence, we calculated hazard maps for $95 \mathrm{~km}$ as well as for $150 \mathrm{~km}$. The difference of the intensity values of both maps are in most cases less than half an intensity.

Recent building codes like the EC 8 recommend a recurrence period of 475 years (probability of exceedance of $10 \%$ in 50 years) for the design earthquake (Fig. 7). In EC 8 a second hazard level for a recurrence period of 95 years (probability of exceedance of $10 \%$ in 10 years) is recommended in addition, to limit the damage of buildings for weaker earthquakes with higher frequency of occurrence (Fig. 8). Special structures like nuclear power plants and large dams are beyond the scope of EC 8. For these structures higher safety standards, including longer recurrence periods, are required, e.g. 2475 years ( $2 \%$ in 50 years) for dams and 10000 to 100000 years for nuclear facilities. Figure 9 shows the seismic hazard for a recurrence period of 10000 years in order to give decision makers first information for regional planning. This does not replace site specific expertises. A hazard curve for Bucharest is extracted from the hazard data set and shown in Fig. 10. 
Acknowledgements. We thank K.-G. Hinzen for his concise review and helpful remarks.

Edited by: P. F. Biagi

Reviewed by: K.-G. Hinzen and another referee

\section{References}

Bala, A., Radulian, M., and Popescu, E.: Earthquake distribution and their focal mechanism in correlation with the active tectonic zones of Romania, J. Geodyn., 36, 129-145, 2003.

Bonjer, K.-P., Oncescu, L., Rizescu, M., Enescu, D., Driad, L., Radulian, M., Ionescu, M., and Moldoveanu, T.: Sourceand Site-Parameters of the 28 April 1999 intermediate-depth VRANCEA Earthquake: First results from the new K2-network in Romania, XXVII General Assembly of the European Seismological Commission, Lisbon, Book of Abstracts and Papers, SSA-2-13-O, 53, 2000.

Bonjer, K.-P., Ionescu, C., Sokolov, V., Radulian, M., Grecu, B., Popa, M., and E. Popescu: Source parameters and ground motion pattern of the 27 October 2004 intermediate depth Vrancea earthquake, EGU General Assembly 2005, EGU05-A-07538, Vienna, 2005.

Cornell, C. A.: Engineering seismic risk analysis, Bull. Seism. Soc. Am., 58, 1583-1606, 1968.

EUROCODE 8: Design of structures for the earthquake resistance. Part 1: General rules, seismic actions and rules for buildings, Draft no. 6, Ref. No: prEN 1998-1:200X, European Committee for Standardisation, Central Secretariat: rue de Strassart 36, B1050 Brussels, 2003.

Fuchs, K., Bonjer, K.-P., Bock, G., Cornea, I., Radu, C., Enescu, D., Jianu, D., Nourescu, A., Merkler, G., Moldoveanu, T., and G. Tudorache: The Romanian earthquake of 4 March 1977, II. Aftershocks and migration of seismic activity, Tectonophysics, 53, 225-247, 1979.

Kövesligethy von, R.: Seismischer Stärkegrad und Intensität der Beben, Gerlands Beiträge zur Geophysik, Band VIII, Leipzig, 1907.

Mäntyniemi, P., Marza, V. I., Kijko, A., and Retief, P.: A New Probabilistic Seismic Hazard Analysis for the Vrancea (Romania) Seismogenic Zone, Nat. Hazards, 29, 371-385, 2003.

Marmureanu, G., Popescu, E., Popa M., Moldovan, A. I., Placinta, A. O., and Ralulian, M.: Seismic Zoning Characterization For The Seismic Hazard Assessment In South-Eastern Romania Territory, Acta Geod. Geoph. Hung., 39, 259-274, 2004.

McGuire, R. K.: FORTRAN Computer Program for Seismic Risk Analysis, US Department of the Interior Geological Survey, Open-File Report, 76-67, 1976.

Musson, R. M. W.: Generalized Seismic Hazard Maps for the Pannonian Basin Using Probabilistic Methods, Pure Appl. Geophys., 157, 147-169, 2000.
Oncescu, M.-C.: Deep structure of Vrancea Region, Romania, inferred from simultaneous inversion for hypocenters and 3-D velocity structure, Ann. Geophys., 2, 23-28, 1984.

Oncescu, M. C. and Trifu, C.-I.: Depth variation of the moment tensor axes in Vrancea (Romania) seismic region, Ann. Geophys., 5B, 149-154, 1987.

Oncescu, M.-C. and Bonjer, K.-P.: A note on the depth recurrence and strain release of large Vrancea earthquakes, Tectonophysics, 272, 291-302, 1997.

Oncescu, M.-C., Marza, V. I., Rizescu, M., and Popa, M.: The Romanian earthquake catalogue between 1984-1997, in: Vrancea earthquakes: tectonics, hazard and risk mitigation, edited by: Wenzel, F., Lungo, D., and Novack, O., Kluwer Academic Publishers, Dordrecht, 43-47, 1999.

Radu, C.: Contribution á l'étude de la sismicité de la Roumanie et comparison avec la sismicité de sud-est de la France, Ph.D. thesis, Université Strasbourg, France, 404 pp., 1974.

Radu C. and Polonic, G.: Characteristics of the 4 March 1977 seismic event, in: The Romanian earthquake of 4 March (in Romanian), 1977, edited by: Balan, St., Cristescu, V., and Cornea, I., Academy Publishing House, Bucharest, 100-136, 1982.

Radu. C. and Utale, A.: Vrancea earthquake of 30 May 1990, Intensity distribution, Contract CFP/IFA 30.86.3/1990 (in Romanian), IV, A2, 1990.

Radulian, M., Vaccari, F., Mandrescu, N., Panza, G. F., and Moldoveanu, C. L.: Seismic Hazard of Romania: Deterministic Approach, Pure Appl. Geophys.. 157, 221-247, 2000.

Radulian, M., Bonjer, K.-P., Popescu, E., Pantea, A., Popa, M., Ionescu, C., Grecu, B., and Constantin, A.: The 27 October 2004 Vrancea (Romania) earthquake, Orfeus Newsletter, in press, 2005.

Sandi, H.: Obstacles to earthquake risk reduction encountered in Romania, in: Earthquake hazard and countermeasures for existing fragile buildings, edited by: Lungu, D. and Saito, T., 261266, 2001.

Shebalin, N. V., Leydecker, G., Mokrushina, N. G., Tatevossian, R. E., Erteleva, O. O., and Vassiliev, V. Yu.: Earthquake Catalogue for Central and Southeastern Europe, European Commission, Report No. ETNU CT 93 - 0087, Brussels, http://www.bgr. de/quakecat, 1998.

Sponheuer, W.: Methoden zur Herdtiefenbestimmung in der Makroseismik. (Methods for depths estimation in macroseismic), Freiberger Forschungs-Hefte C 88, 117 pp., Akademie Verlag Berlin, 1960..

Trifu, C. I., Deschamps, A., Radulian, M., and Lyon-Caen, H.: The Vrancea earthquake of May 30, 1990: An estimate of the source parameters, Proc. of the XXIInd ESC Gen. Ass., Barcelona, 1990, 1, 449-454, 1992. 